\section{Plasma prostaglandins in fulminant hepatic failure}

Some prostaglandins are potent hypotensive agents, and the liver and lungs are important sites for their inactivation in animals. Although the importance of this function in human liver is not known, it seemed possible that raised blood prostaglandin levels could accompany massive hepatic necrosis and contribute to the hypotension commonly found in patients with fulminant hepatic failure (FHF). We have therefore measured plasma levels of prostaglandin-like material in nine patients with FHF, all of whom were in grade IV coma $^{3}$ and seven had been treated 12-18 hours previously with haemoperfusion through a column of coated charcoal. ${ }^{3}$ Five were hypotensive and four were normotensive. We also investigated possible removal of prostaglandins by a charcoal column during haemoperfusion in four patients. Only one patient (No 5 in the table) had undergone peritoneal dialysis before the blood samples were taken.

\section{Methods and results}

Blood samples from right atrial or peripheral arterial catheters, and from the input and output lines to the charcoal column, were put into lithium heparin tubes containing indomethacin $(10 \mu \mathrm{g} / \mathrm{ml})$. The plasma was immediately separated by centrifugation and stored at $-20^{\circ} \mathrm{C}$, usually for less than three weeks. Prostaglandin-like material was extracted ${ }^{4}$ and bionssayed against prostaglandin $\mathrm{E}_{2}$ on the rat stomach strip in the presence of various drugs to increase sensitivity and selectivity. ${ }^{4}$. The levels appeared normal in eight patients, but were raised in one of two samples from anotlier patien (No 8 in the table). They were similar in the hypotenaive and rormotensive patients and were unrelated to the severity of liver damage as assessed by the prothrombin time. There was no significant difference between prostaglandin levels in the blood entering and leaving the charcoal coltumn $(0 \cdot 11 \pm$ 0.03 (SE) and $0.09 \pm 0.03 \mathrm{ng}$ prostaglandin $\mathrm{E}_{2}$ equivalents $/ \mathrm{ml}$ respectively, $\mathbf{n}=4)$.

\begin{tabular}{|c|c|c|c|c|c|}
\hline Patients & $\begin{array}{c}\text { Blood } \\
\text { pressure } \\
\text { (mm Hg) }\end{array}$ & $\begin{array}{c}\text { Days after } \\
\text { onset of } \\
\text { grade IV } \\
\text { coma }\end{array}$ & $\begin{array}{c}\text { Prothrombin } \\
\text { time } \\
(\mathrm{s})\end{array}$ & $\begin{array}{l}\text { Plasma } \\
\text { sample }\end{array}$ & $\begin{array}{l}\text { Prostaglandin } \\
\text { levels } \\
\text { (ng/mi PGE } \\
\text { equivalents) } \\
\end{array}$ \\
\hline $\begin{array}{c}\text { Hypotensive } \\
1 \\
2 \\
3 \\
4 \\
5\end{array}$ & $\begin{array}{l}90 / 30 \\
80 / 40 \\
90 / 40 \\
80 / 50 \\
80 / 50 \\
70 / 40 \\
80 / 40\end{array}$ & $\begin{array}{l}2 \\
4 \\
4 \\
2 \\
1 \\
1 \\
3\end{array}$ & $\begin{array}{l}58 / 13 \\
60 / 13 \\
68 / 13 \\
26 / 13 \\
51 / 13 \\
49 / 13 \\
45 / 13\end{array}$ & $\begin{array}{l}\text { Arterial } \\
\text { Venous } \\
\text { Arterial } \\
\text { Arterial } \\
\text { Venous } \\
\text { Venous } \\
\text { Venous }\end{array}$ & $\begin{array}{r}<0.01 \\
0.06 \\
0.03 \\
0.02 \\
<0.01 \\
<0.01 \\
<0.01\end{array}$ \\
\hline Normotensive & $\begin{array}{l}140 / 70 \\
140 / 70 \\
120 / 70 \\
120 / 80 \\
120 / 80 \\
110 / 60\end{array}$ & $\begin{array}{r}6 \\
15 \\
1 \\
1 \\
3 \\
3\end{array}$ & $\begin{array}{l}18 / 13 \\
20 / 13 \\
2713 \\
47 / 13 \\
50 / 13 \\
24 / 14\end{array}$ & $\begin{array}{l}\text { Arterial } \\
\text { Venous } \\
\text { Venous } \\
\text { Venous } \\
\text { Venous } \\
\text { Arterial }\end{array}$ & $\begin{array}{r}<0.01 \\
<0.01 \\
0.05 \\
0.92 \\
<0.01 \\
0.08\end{array}$ \\
\hline
\end{tabular}

Plasma levels of prostaglandin-like activity were not raised in patients with fulminan hepatic failure and appeared similar in hypotensive and normotensive subjects

\section{Discussion}

The normal levels of plasma prostaglandin-like activity found in patients with FHF suggests that if prostaglandin $\mathrm{E}$ or $\mathrm{F}$ compounds were released into the circulation they were adequately metabolised in sites other than the liver (for example, the lungs ${ }^{1}$ ). Prostaglandin A compounds are also potent hypotensive agents possibly occurring in blood, but unlike E-type and F-type prostaglandins they substantially resist inactivation by the lungs. ${ }^{5}$ We cannot comment on the possibility that they contributed to the hypotension, since low levels are not detected by the rat stomach assay. Previous charcoal haemoperfusion would seem unlikely to produce lowered prostaglandin levels several hours later, and low plasma levels were also found in the two unperfused patients. Although the mean level was lower in the blood leaving the coated-charcoal column than in the blood entering it, the difference was not statistically significant. Nevertheless, only four patients were studied, and paired measurements were made after only a single pass through the column.

The present results suggest that plasma levels of prostaglandin $\mathbf{E}$ or $\mathrm{F}$ compounds are not raised in patients with $\mathrm{FHF}$, and are not responsible for the hypotension and low peripheral resistance commonly seen.

We thank Mrs E Charlier (supported by the Wellcome Trust) and Mr I F Stamford for technical assistance.
1 Ferreira, S H, and Vane, J R, Nature, 1967, 216, 868.

2 Rueff, B; and Benhamou, J P, Gut, 1973, 14, 805.

3 Gazzard, B G, et al, Lancet, 1974, 1, 1301.

4 Unger, W G, Stamford, I F, and Bennett, A, Nature, 1971, 233, 336.

${ }^{5}$ Kadowitz, P J, Joiner, P D, and Hyman, A L, Annual Review of Pharmacology, 1975, 15, 185 .

Liver Unit and Department of Surgery, King's. College Hospital Medical School, London SE5 8RX

PETER TREWBY, MB, MRCP, medical registrar

ALAN BENNETT, PHD, reader

IAIN M MURRAY-LYON, MD, MRCP, senior lecturer

ROGER WILLIAMS, MD, FRCP, physician and director of liver unit

\section{Steatorrhoea complicating therapy with mefenamic acid}

A number of drugs such as cholestyramine, neomycin, PAS, colchicine; and phenolphthalein may induce malabsorptive states. ${ }^{1}$ We can find no record of a case of steatorrhoea accompanying therapy with mefenamic acid, and we report its occurrence in one patient during prolonged use of this analgesic.

\section{Case history}

The patient, a retired schoolmaster, aged 65, was admitted to another hospital in April 1972 for investigation of diarrhoea. He had been taking $250 \mathrm{mg}$ mefenamic acid three times a day since 1970 for osteoarthritis and glyceryl trinitrate for angina since 1968 . Clinical examination showed only haemorrhoids. The faecal fat output was $43 \mathrm{~g}$ over 5 days and a barium enema showed a stricture of the sigmoid colon associated with diverticular disease. Nothing abnormal was found at laparotomy. He was discharged without change in his therapy. In October 1973 he was readmitted because of persisting diarrhoea. The faecal fat was $49.6 \mathrm{~g}$ over 3 days. He was treated empirically with Lomotil and pancreatic enzyme supplements.

In September 1974 his bowel actions were up to 10 a day with pale, offensive stools. He was admitted to the Manchester Royal Infirmary. Treatment with mefenamic acid, glyceryl trinitrate, Pancrex (16 tablets daily), and Lomotil (10 tablets daily) was continued. Investigations confirmed the presence of steatorrhoea with a 3-day faecal fat output of $38 \mathrm{~g}$. The results of the investigation of the following were normal: haemoglobin serum iron, folate, B12, calcium, albumin; xylose tolerance test; jejunal biopsy (both histological appearance and disaccharidase levels); barium meal, follow through, and barium enema. All drug therapy was discontinued, including mefenamic acid, and within two days the diarrhoea ceased. The faecal fat output two weeks later was normal at $12.9 \mathrm{~g}$ in 3 days. The patient remained well after discharge. He started taking glyceryl trinitrate again without a recurrence of diarrhoea. He refused a controlled challenge with mefenamic acid.

\section{Comment}

Steatorrhoea as a complication of mefenamic acid treatment should be considered in all cases presenting with diarrhoea, which is a common and well-recognised adverse reaction. In the case reported here studies of jejunal morphology and enzymology were normal, and implies that mefenamic acid may impair the intraluminal phase of fat absorption by acting like neomycin in causing bile salt precipitation ${ }^{2}$ or inhibition of lipase activity.

1 Dobbins, W O, Gastroenterology, 1968, 54, 1193.

2 Thompson, G R, MacMahon, M, and Claes, P, European fournal of Clinical Investigation, 1970, 1, 40.

4 Mehta, S K, Weser, E, and Sleisenger, M H, fournal of Clinical Investigation, $1964,43,1252$.

University Department of Gastroenterology, Manchester Royal Infirmary, Manchester M13 9WL

J S MARKS, BM, MRCP, senior house officer

M H GLEESON, MB, MRCP, senior registrar 